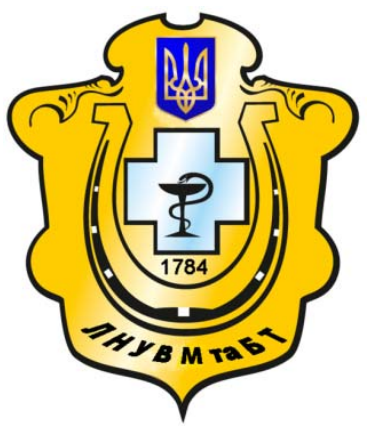

Науковий вісник Львівського національного університету ветеринарної медицини та біотехнологій імені С.3. Гжицького

Scientific Messenger of Lviv National University of Veterinary Medicine and Biotechnologies named after S.Z. Gzhytskyj

doi:10.15421/nvlvet7009

ISSN 2413-5550 print

ISSN 2518-1327 online

$\underline{\text { http://nvlvet.com.ua/ }}$

УДК 619:612.017:598.261.7

\title{
Функціонування імунної системи перепелів в різні періоди постнатального онтогенезу
}

\author{
В.Г. Стояновський, Л.С. Гармата, І.А. Коломієць \\ i_kolomiec@mail.ru
}

\begin{abstract}
Львівський наџіональний університет ветеринарної медицини та біотехнологій імені С.3. Гжицького, вул. Пекарська, 50, м. Львів, 79010, Украӥна
\end{abstract}

\begin{abstract}
У статті наведені результати дослідження основних морфометричних характеристик органів імуногенезу перепелів породи «Фараон» промислового вирошування в різні періоди постнатального онтогенезу. Встановлено найвищі числові значення показника відносної маси та індекс тимуса, бурси, селезінки перепелів породи «Фараон» у 5-добовому віці. Виявлено, що абсолютна маса тимуса перепелів збільшується до 33 доби життя, бурси Фабрииіуса - до 53 доби життя і селезінки - до 240 доби життя. Установлено, що з початком несучості (53 mа 75 доба життя) і до 240-добового віку в перепелів відносна маса та індекс тимуса знижується в п'ять разів ( $p<0,01-0,001)$, бурси Фабричіуса- втричі $(p<0,05-$ 0,01). Досліджено зменшення відносної маси та індексу селезінки втричі у перепелів з 20 до 240 доби життя. Отримані дані вказують на зміну імунологічної реактивності організму перепелів в різні вікові періоди, і насамперед, в продуктивний яйценосний період, а також на початок вікової інволючії тимуса, бурси Фабричіуса. Вірогідне зменшення індексу бурси нижче 1,0 у перепелів з 75 до 240 доби життя може вказувати на пригнічення $B$ - ланки імунітету, тобто зменшення утворення $B$ - лімфоцитів. Зменшення відносної маси та індексу селезінки перепелів втричі з 20 до 240 доби життя на фоні зменшення аналогічного показника тимусу і бурси Фабрииіуса може свідчити про зниження компенсаторних можливостей організму птиці.
\end{abstract}

Ключові слова: імунна система, тимус, бурса Фабриціуса, селезінка, перепели, постнатальний онтогенез, критичні періоди, вікова інволючія.

\section{Функционирования иммунной системы перепелов в разные периоды постнатального онтогенеза}

\author{
В.Г. Стояновский, Л.С. Гармата, И.А. Коломиец \\ i_kolomiec@mail.ru
}

\begin{abstract}
Львовский национальный университет ветеринарной медицины и биотехнологий имени С.3. Гжиикого, ул. Пекарская, 50, г. Львов, 79010, Украина
\end{abstract}

В статье приведены результаты исследования основных морфометрических характеристик органов иммуногенеза перепелов породы «Фараон» промышленного вырашивания в разные периоды постнатального онтогенеза. Установлены самые высокие числовые значения показателя относительной массы и индекс тимуса, бурсы, селезенки перепелов породы «Фараон» в 5-суточном возрасте. Выявлено, что абсолютная масса тимуса перепелов увеличивается до 33 суток жизни, бурсы Фабрициуса - до 53 суток жизни и селезенки - до 240 суток жизни. Установлено, что с началом яйщеноскости (53 и 75 сутки жизни) и к 240-суточному возрасту в перепелов относительная масса и индекс тимуса снижсается в пять раз $(p<0,01-0,001)$, бурсы Фабрициуса - втрое $(p<0,05-0,01)$. Исследовано уменьшение относительной массы и индекса селезенки втрое у перепелов с 20 по 240 сутку жизни. Полученные данные указывают на изменение иммунологической реактивности организма перепелов в разные возрастные периоды, и прежде всего, в производительный яйщеносный период, а также на начало возрастной инволючии тимуса, бурсы Фабрициуса.

Достоверное уменьшение индекса бурсы ниже 1,0 у перепелов с $75 \kappa 240$ суткам жизни может указывать на подавление В-звена иммунитета, то есть уменьшение образования В - лимфочитов. Уменьшение относительной массы и индекса

\section{Citation:}

Stojanovskyj, V.G., Garmata, L.S., Kolomijets, I.A. (2016). Function of quail immune system at different periods of postnatal ontogenesis. Scientific Messenger LNUVMBT named after S.Z. Gzhytskyj, 18, 3(70), 36-39. 
селезенки перепелов втрое с 20 к 240 суткам жизни на фоне уменьшения аналогичного показателя тимуса и бурсы Фабрициуса может свидетельствовать о снижении компенсаторных возможностей организма птицьы.

Ключевые слова: иммунная система, тимус, бурса Фабрициуса, селезенка, перепела, постнатальный онтогенез, критические периоды, возрастная инволюччия.

\title{
Function of quail immune system at different periods of postnatal ontogenesis
}

\author{
V.G. Stojanovskyj, L.S. Garmata, I.A. Kolomijets \\ i_kolomiec@mail.ru \\ Lviv national university of veterinary medicine and biotechnologies named after S. Gzhytskyj, \\ Pekarska Str., 50, Lviv, 79010, Ukraine
}

\begin{abstract}
In the article are given results concerning main morphometric characteristics of immunogenesis organs in "Pharaon" breed of quails of industrial raising during different periods of postnatal ontogenesis. It is established that highest numeric values of relative mass index and thymus, Fabricius bursa, spleen of quail species "Pharaoh» in 5 days age. It was found that the vast mass of the thymus quail increased to 33 days of life, Fabricius bursa - up to 53 days of life and spleen - up to 240 days of life. It was established that with the egg (53 and 75 day life) and 240-day old quail in the relative weight and thymus index decreased five times $(p<0,01-0,001)$ seminary Fabricius bursa - three times $(p<0,05-0,01)$. It was investigated that the relative reduction of mass and spleen index in three quails from 20 to 240 days of life. The data indicate a change of immunological reactivity quail in different age periods, especially in the productive oviparous period and the beginning age involution of the thymus, Fabricius bursa. The possible reduction of the seminary index below 1.0 in quails from 75 to 240 days of life may indicate suppression of B-immunity, that reduce the formation of $B$-lymphocytes. The reduction of the relative weight and spleen index quail tripled from 20 to 240 days of life on the background of declining same period of the thymus and Fabricius bursa may indicate a compensatory reduction of the organism poultry.
\end{abstract}

Keywords: immune system, thymus, Fabricius bursa, spleen, quails, postnatal ontogenesis, critical periods, involution.

\section{Вступ}

Як відомо, вирощування і розведення перепелів є високо рентабельною галуззю птахівництва, оскільки їх організм характеризується інтенсивним метаболізмом, що обумовлює швидкість росту, розвитку та рівень несучості (Gushhin and Kroik, 2003; Gunchak and Ratych, 2012). На сьогоднішній день доведено, що в зв'язку з великим продуктивним навантаженням на організм перепелів промислового вирощування, знижується імунний статус організму і підвищується сприйнятливість до різноманітних інфекцій, що скорочує термін їх продуктивного використання (Ibatulin et al., 2002; Kurinna, 2013). Дослідженню органів імунної системи перепелів породи «Фараон» у віковому аспекті присвячено ряд робіт, за результатами яких виявлено ранню стадію фізіологічної незрілості (1 10 днів після виведення перепелят), стадію фізіологічної гіперплазії органів імунної системи (1,5 2,5 місяці після виводу) і стадію вікової (акцидентальної) інволюції (через 2,5 місяців після виведення і далі) (Dore, 1994; Zajceva et al., 2011). Авторами виявлено, що вище названі органи імунної системи перепелів продовжують свій розвиток після виведення і завершують його до початку несучості. Це явище ними охарактеризовано, як вікова (фізіологічна) імунна недостатність. В той час, коли за даними інших дослідників, відзначається збільшення органометричних показників органів імуногенезу перепелів у віковому аспекті до 180-добового віку (Tubol, 2009). Отже, отримані дослідниками результати є суперечливі і потребують більш детального вивчення. Метою нашої роботи було з'ясувати фізіологічні та морфологічні зміни центральних і периферичних органів імунної системи перепелів породи «Фараон» промислового вирощування в різні періоди постнатального онтогенезу.

\section{Матеріал і методи досліджень}

Дослід було проведено в умовах птахофабрики ПП Залізний с. Долиняни, Городоцького р-ну, Львівської області. Для виконання завдання до ранкової годівлі у 5-, 20-, 33-, 53-, 75-, 90-, 150-, 240-добовому віці було відібрано клінічно здоровий молодняк перепелів породи «Фараон» та проведено їх зважування. Для досягнення поставленої мети був проведений забій перепелів (по 5 особин в кожному віковому періоді), при якому для досліджень відібрано тимус, бурсу Фабриціуса, селезінку. Для морфометричного аналізу після ї препарування визначали абсолютну масу органів за допомогою вагів лабораторних технічних 4 класу точності (ВЛКТ-500 М) та відносну масу органів. Індекс тимуса, бурси Фабриціуса, селезінки визначали як відношення маси цих органів (г) до маси тіла птиці (г), помноженого на 1000 (Gucol and Kondrat'ev, 1989). Визначали ступінь вірогідності різниці (р) між досліджуваними показниками перепелів 5-добового віку, порівняно з усіма іншими віковими групами, за допомогою програми Statystika для Windows XP з використанням t-критерію Стьюдента.

\section{Результати та їх обговорення}

За результатами отриманих досліджень було встановлено, що у перепелів 5-добового віку абсолютна маса тимуса, бурси та селезінки складала $0,075 \pm$ 0,034 г, 0,045 $\pm 0,018$ г і 0,045 $\pm 0,011$ г. Маса бурси i селезінки виявилися найнижчими у порівнянні 3 наступними віковими періодами (таблиця 1), проте відносна маса та індекси досліджуваних нами органів імуногенезу перепелів 5-добового віку були найвищими, порівняно з перепелами старших вікових груп (таблиця 2, 3). Отримані результати можуть вказувати на високий рівень специфічних імуноморфологічних 
реакцій, матеріальним субстратом імунної відповіді яких являється тимус, бурса та селезінка у перепелів 5-добового віку.

На 20 добу життя перепелів виявлено вірогідне зростання абсолютної маси тимуса до $0,361 \pm 0,068$ г $(\mathrm{p}<0,01)$, а також тенденцію до зростання величини цього показника стосовно бурси та селезінки. В цей період спостерігали зменшення відносної маси та індексу бурси та селезінки втричі (таблиця 2, 3).

На 33 добу життя перепелів абсолютна маса тимуса збільшувалася у вісім разів $(\mathrm{p}<0,001)$, що вияви- лося найвищим, порівняно з усіма віковими групами. Вірогідно зростала абсолютна маса бурси та селезінки $(\mathrm{p}<0,05)$. Індекс тимуса і бурси залишався без змін, а індекс селезінки знижувався до $0,082 \pm 0,056$.

На 90 добу життя перепелів виявлено зменшення абсолютної маси тимуса, бурси, вірогідне зменшення їх відносної маси та індексу, тоді коли абсолютна маса селезінки залишалася вдвічі вищою $(\mathrm{p}<0,05)$, порівняно з вихідним періодом експерименту.

Абсолютна маса органів імуногенезу перепелів породи «Фараон» у критичні періоди онтогенезу, г, $(\mathrm{M} \pm \mathrm{m}, \mathrm{n}=\mathbf{5})$

\begin{tabular}{|c|c|c|c|}
\hline Вік перепелів, діб & Тимус & Бурса Фабриціуса & Селезінка \\
\hline 5 доба життя & $0,075 \pm 0,034$ & $0,045 \pm 0,018$ & $0,045 \pm 0,011$ \\
\hline 20 доба життя & $0,361 \pm 0,068^{* *}$ & $0,092 \pm 0,041$ & $0,085 \pm 0,042$ \\
\hline 33 доба життя & $0,834 \pm 0,092^{* * *}$ & $0,234 \pm 0,050^{*}$ & $0,144 \pm 0,070^{*}$ \\
\hline 53 доба життя & $0,112 \pm 0,089$ & $0,383 \pm 0,066^{* * *}$ & $0,273 \pm 0,065^{* *}$ \\
\hline 75 доба життя & $0,104 \pm 0,067$ & $0,145 \pm 0,019^{*}$ & $0,151 \pm 0,020^{*}$ \\
\hline 90 доба життя & $0,135 \pm 0,018$ & $0,091 \pm 0,038$ & $0,224 \pm 0,070^{*}$ \\
\hline 150 доба життя & $0,085 \pm 0,035$ & $0,060 \pm 0,023$ & $0,235 \pm 0,068^{*}$ \\
\hline 240 доба життя & $0,025 \pm 0,013$ & $0,053 \pm 0,029$ & $0,525 \pm 0,130^{* *}$ \\
\hline
\end{tabular}

У перепелів від 53- до 240-добового віку спостерігали поступову тенденцію до зменшення абсолютної маси тимуса (табл. 1). На 53 добу життя абсолютна маса бурси досягла свого найвищого числового значення, що складало відповідно 0,383 $\pm 0,066$ г ( $<<0,001)$, порівняно 3 усіма віковими періодами. Абсолютна маса селезінки збільшилася в 2,5 раза $(\mathrm{p}<0,01)$, порівняно 3 вихідним періодом експерименту. Відносна маса та індекс тимуса зменшилися до $0,035 \pm 0,020 \%$ та $0,33 \pm 0,25(\mathrm{p}<0,05-0,01)$, в той час коли величини цих показників стосовно бурси та селезінки залишалися на рівні попередніх вікових періодів.

У перепелів від 75- до 240-добового віку спостерігали поступову тенденцію до зменшення абсолютної маси бурси Фабриціуса. На 75 добу життя виявлено вірогідне зменшення відносної маси та індексу тимуса в п'ять разів, бурси та селезінки - втричі (табл. 2, 3).

Відносна маса органів імуногенезу перепелів породи «Фараон» у критичні періоди онтогенезу, \%

Таблиия 2 $(\mathbf{M} \pm \mathbf{m}, \mathbf{n}=\mathbf{5})$

\begin{tabular}{|l|l|l|l|}
\hline Вік перепелів, діб & Тимус & Бурса Фабриціуса & Селезінка \\
\hline 5 доба життя & $0,577 \pm 0,152$ & $0,351 \pm 0,082$ & $0,357 \pm 0,096$ \\
\hline 20 доба життя & $0,412 \pm 0,134$ & $0,122 \pm 0,051^{*}$ & $0,112 \pm 0,043^{*}$ \\
\hline 33 доба життя & $0,443 \pm 0,115$ & $0,135 \pm 0,040^{*}$ & $0,082 \pm 0,056^{*}$ \\
\hline 53 доба життя & $0,035 \pm 0,020^{*}$ & $0,146 \pm 0,704$ & $0,101 \pm 0,055^{*}$ \\
\hline 75 доба життя & $0,046 \pm 0,013^{* *}$ & $0,051 \pm 0,015^{* *}$ & $0,063 \pm 0,032^{* *}$ \\
\hline 90 доба життя & $0,042 \pm 0,019^{* *}$ & $0,033 \pm 0,018^{* *}$ & $0,068 \pm 0,049^{* *}$ \\
\hline 150 доба життя & $0,026 \pm 0,018^{* * *}$ & $0,019 \pm 0,013^{* *}$ & $0,073 \pm 0,050^{* *}$ \\
\hline 240 доба життя & $0,008 \pm 0,005^{* * *}$ & $0,016 \pm 0,014^{* * *}$ & $0,161 \pm 0,080$ \\
\hline
\end{tabular}

Таблиия 3

Індекс органів імуногенезу перепелів породи «Фараон» у критичні періоди онтогенезу, $(\mathrm{M} \pm \mathbf{m}, \mathbf{n}=5)$

\begin{tabular}{|c|c|c|c|}
\hline Вік перепелів, діб & Тимус & Бурса Фабриціуса & Селезінка \\
\hline 5 доба життя & $5,77 \pm 1,85$ & $3,51 \pm 1,09$ & $3,57 \pm 0,92$ \\
\hline 20 доба життя & $4,10 \pm 0,90$ & $1,19 \pm 0,40^{*}$ & $1,04 \pm 0,46^{*}$ \\
\hline 33 доба життя & $4,37 \pm 0,91$ & $1,24 \pm 0,37^{*}$ & $0,74 \pm 0,30^{* *}$ \\
\hline 53 доба життя & $0,33 \pm 0,15^{* *}$ & $1,35 \pm 0,55$ & $1,06 \pm 0,39^{*}$ \\
\hline 75 доба життя & $0,38 \pm 0,26^{* *}$ & $0,45 \pm 0,20^{* *}$ & $0,57 \pm 0,29^{* *}$ \\
\hline 90 доба життя & $0,42 \pm 0,29^{* *}$ & $0,33 \pm 0,25^{* *}$ & $0,68 \pm 0,35^{* *}$ \\
\hline 150 доба життя & $0,26 \pm 0,08^{* *}$ & $0,19 \pm 0,11^{* * *}$ & $0,73 \pm 0,42^{* *}$ \\
\hline 240 доба життя & $0,08 \pm 0,04^{* * *}$ & $0,16 \pm 0,10^{* * *}$ & $1,61 \pm 0,55$ \\
\hline
\end{tabular}

На 150 та 240 добу життя встановлено подальше зниження абсолютної маси тимуса і бурси, що складало відповідно 0,025 $\pm 0,013$ г та 0,053 $\pm 0,029$ г. Найнижчими виявився показник відносної маси та індексу тимуса в п'ять разів і бурси втричі перепелів
150- та 240- добового віку у порівнянні до вихідного періоду - 5 діб ( $<0,01-0,001)$. Що стосується селезінки, то встановлено що в період 3150 до 240 доби життя їі абсолютна маса збільшилася вдвічі $(\mathrm{p}<0,01)$. Порівняно $з$ вихідним віковим періодом, величина 
цього показника зросла в п’ять разів $(\mathrm{p}<0,01)$. Проте, відносна маса та індекс селезінки у перепелів на 240 добу життя був нижчим втричі, порівняно 3 птицею 5-добового віку.

За даними літератури, зменшення бурсального індексу до 1,0 і нижче та індексу тимусу до 1,5 і нижче свідчать про розвиток імунодефіцитного стану (Birman and Gromov, 2001; Yoshimura et al., 2005). Отримані нами результати досліджень вказують на вірогідне зниження відносної маси та індексу тимуса в перепелів 353 до 240 доби життя, що може свідчити про зміну специфічних імуноморфологічних реакцій, матеріальним субстратом імунної відповіді яких являється тимус, а також про початок його вікової інволюції. Вірогідне зменшення індексу бурси нижче 1,0 у перепелів 375 до 240 доби життя (продуктивний яйценосний період) може вказувати на пригнічення Вланки імунітету, тобто зменшення утворення В - лімфоцитів, а також про початок іiї вікової інволюції. Зменшення відносної маси та індексу селезінки перепелів втричі з 20 до 240 доби життя на фоні зменшення аналогічного показника тимусу і бурси Фабриціуса може свідчити про зниження компенсаторних можливостей організму птиці.

\section{Висновки}

1. Встановлено найвищі числові значення показника відносної маси та індекс тимуса, бурси, селезінки перепелів породи «Фараон» у 5-добовому віці. Абсолютна маса тимуса перепелів збільшується до 33 доби життя, бурси Фабриціуса - до 53 доби життя і селезінки - до 240 доби життя.

2. Установлено, що з початком несучості (53 та 75 доба життя) і до 240-добового віку в перепелів відносна маса та індекс тимуса знижується в п'ять разів (р $<0,01-0,001)$, бурси Фабриціуса - втричі ( $\mathrm{p}<0,05-$ 0,01). Виявлено, що відносна маса та індекс селезінки зменшується втричі у перепелів 320 до 240 доби житТя.

Перспективи подальших досліджень бачимо у проведенні морфометричного аналізу органів імуно- генезу перепелів у критичні періоди постнатального онтогенезу на гістологічному рівні.

\section{Бібліографічні посилання}

Gushhin, V., Kroik, L. (2003). Perepelovodstvo dolzhno razvivat'sja. Pticevodstvo. 6, 22-23 (in Ukrainian).

Gunchak, A.V., Ratych, I.B. (2012). Jakist' jajec' i produktyvnist' perepilok za riznogo rivnja jodu $\mathrm{v}$ i'h racionah. Visnyk agrarnoi' nauky. 6, 41-43 (in Ukrainian).

Ibatulin, I.I., Slobodjanjuk, N.M., Otchenashenko, V.V. (2002). Produktyvnist' perepeliv za riznyh rivniv godivli. Visnyk Bilocerkiv. derzh. agrar. un-tu. 22, 62-69 (in Ukrainian).

Kurinna, A.S. (2013). Vikova dynamika pokaznykiv rostu perepeliv riznyh generacij. Suchasne ptahivnyctvo. 9, 21-23 (in Ukrainian).

Dore, M. (1994). Immunomorfogenez u perepelov pri estestvennom rahite i osteomaljacii. Nauch.-tehn. konf. Rol' nauki i peredovogo opyta v s. - h. roizssdstve Vyp. Odesskogo SHI. Odessa. 13, 23-27 (in Ukrainian).

Zajceva, E.V., Tel'cov, L.P., Seleznev, S.B. i dr. (2011). Morfologija immunnoj sistemy ptic. Brjansk: Ladomir (in Russian).

Tubol, O.V. (2009). Adaptivnye preobrazovanija selezenki japonskih perepelov: sb. nauch.tr. Problemy i perspektivy sovremennoj nauki. Tomsk. 2, 1, 14 (in Russian).

Gucol, A.A., Kondrat'ev, B.Ju. (1988). Prakticheskaja morfometrija organov i tkanej: Dlja vrachejpatologoanatomov. Tomsk: Izd. Tom. un-ta (in Russian).

Birman, B.Ja., Gromov, I.N. (2001). Immunodeficity u ptic. Minsk: Biznesofest.

Yoshimura, Y., Nagano, K., Subedi, K., Kaiya, H. (2005). Identification of Immunoreactive Ghrelin and its mRNA in the Oviduct of Laying Japanese Quail, Coturnix japonica. The J. of Reprod. Science, 42 (4), 291-300.

Стаття надійшла до редакції 8.10.2016 